\title{
Fermentation and distillation of cheese whey: Carbon dioxide-equivalent emissions and water use in the production of whey spirits and white whiskey
}

\author{
Derrick Risner, ${ }^{*}$ Avi Shayevitz, ${ }^{*}$ Karl Haapala, $†$ Lisbeth Meunier-Goddik, ${ }^{* 1}$ and Paul Hughes ${ }^{* 1}$ \\ *Department of Food Science and Technology, and \\ †School of Mechanical, Industrial, and Manufacturing Engineering, Oregon State University, Corvallis 97331
}

\begin{abstract}
Whey disposal can be both an environmental and economic challenge for artisanal creameries. Lactose in whey can be fermented to produce ethanol and subsequently distilled. The objective of this study was to use a process-based life cycle analysis to compare carbon dioxide-equivalent $\left(\mathrm{CO}_{2} \mathrm{e}\right)$ emissions and water usage associated with the artisanal or craft production of clear, unaged spirits using whey or malted barley as fermentation substrate. Differences in production were assessed based on key process differences: energy used, water used, distillation by-product disposal, and mass of $\mathrm{CO}_{2}$ produced during fermentation. For this study, whey was assumed removed from the artisanal creamery waste stream. Quantifiable differences were evaluated per $750-\mathrm{mL}$ ( $45 \%$ alcohol by volume) functional unit and expressed as mass-equivalent $\mathrm{CO}_{2}$ emissions $(\mathrm{kg}$ of $\mathrm{CO}_{2} \mathrm{e}$ ) and mass of water $(\mathrm{kg})$ used. The $\mathrm{CO}_{2} \mathrm{e}$ emissions and water usage were quantified using published data, thermodynamic calculations, and mass-balance calculations for a hypothetical distillation system. The process-based life cycle analysis estimated that distillation of fermented whey reduced overall $\mathrm{CO}_{2} \mathrm{e}$ emissions by $8.4 \mathrm{~kg}$ per functional unit and required $0.44 \mathrm{~kg}$ less water added into the production process compared with production of a similar clear, unaged spirit using malted barley as substrate. Our preliminary analysis suggests that conversion to distilled whey spirit is a more environmentally responsible approach compared with landfill disposal of whey.
\end{abstract}

Key words: carbon, life cycle analysis, artisanal creamery waste, distilled whey spirit

\footnotetext{
Received September 25, 2017.

Accepted December 2, 2017.

${ }^{1}$ Corresponding authors: lisbeth.goddik@oregonstate.edu and paul. hughes@oregonstate.edu
}

\section{INTRODUCTION}

The hallmark of a sustainable business is a balanced approach to economic, environmental, and social responsibility - a sustainable business aims to have a positive role in the community while maintaining profitability. In the dairy industry, particularly among small and medium-sized artisanal cheese makers, whey remains an important waste effluent that can have a profound impact both economically and environmentally. Whey consists of 93 to $94 \%$ water and contains lactose, protein, minerals, lactic acid, and fats (Prazeres et al., 2012). The concentration of lactose (4.5-5.0\%) in whey gives it a biochemical oxygen demand (BOD) of 30 to $50 \mathrm{~g} / \mathrm{L}$ and chemical oxygen demand (COD) of 60 to $80 \mathrm{~g} / \mathrm{L}$ (Siso, 1996; Guimarães et al., 2010; Chatzipaschali and Stamatis, 2012). Much of the whey produced today is converted to value-added powders, which requires technology operating at a scale that is not commercially viable for artisanal creameries.

Instead, small to medium-sized artisanal creameries dispose of whey using traditional methods, such as land disposal, animal feed, or at a municipal or private water treatment facility. Several problems are associated with such disposal of whey, including cost due to shipment of whey, fees charged by waste management facilities, and limits imposed on production volumes due to local environmental restrictions. Thus, there is a need to develop low-cost technologies to convert small volumes of whey into value-added products.

Research into using cheese whey as a substrate for ethanol production has been ongoing for the past $75 \mathrm{yr}$ (Whittier, 1944; Rogosa et al., 1947; Guimarães et al., 2010) and has focused primarily on fermentation optimization. During fermentation, sugar is converted into ethanol and carbon dioxide at a near-equal (wt/wt) ratio (Lewis and Young, 2002). Under ideal conditions, raw fermented whey yields 2 to $3 \%$ (wt/vol) ethanol (Koushki et al., 2012). Many strains of Kluyveromyces marxianus have the ability to break down lactose into fermentable sugar monomers without the need for further processing (Dragone et al., 2011; Diniz et al., 
2014; Hadiyanto et al., 2014). In spite of interest in whey as a substrate for ethanol production, relatively little research has focused on the use of fermented whey to produce a distilled whey spirit (DWS) for human consumption. Research related to consumable DWS has included the gas chromatography analysis of volatile compounds found in DWS and subsequent comparison to traditional spirits (Dragone et al., 2009). The craft spirit market has been expanding steadily for the last $10 \mathrm{yr}$ (Lozier, 2017) and the development of novel products could allow distilleries to develop an economic edge. Currently, several craft distilleries are producing commercial examples of "milk vodka," such as Black Cow vodka (Black Cow, 2017) and Vermont White vodka (Vermont White, 2016).

This study compared the environmental impact of DWS production to that of an unaged, clear spirit produced from malted barley, commonly referred to as white whiskey (WW). The justification for comparing DWS with WW production is the assumption that DWS would replace other clear spirits on the market and should therefore not have a negative environmental impact compared with existing clear spirits. Ideally, removal of unprocessed whey from a creamery waste stream should effectively reduce the overall environmental impact of the latter.

White whiskey is frequently produced by craft distillers, who would be logical end-users of whey generated by small, artisanal creameries. It should also be noted that the production processes for WW and DWS are similar; a distillery producing WW could easily shift production to DWS without the need for additional investments in infrastructure. Each process produces an unaged, clear spirit that could be marketed as a craft spirit and sold at a premium price.

\section{MATERIALS AND METHODS}

A process-based life cycle analysis (LCA), following the ISO 14040 and 14044 frameworks (ISO, 2006), was used to compare the differences in processes and environmental impacts (Scientific Applications International Corporation, 2006). The process-based LCA consists of 4 steps, which are used to identify goal and scope of LCA, define processing input and outputs, quantify key environmental impacts, and draw conclusions from the information obtained (Figure 1). Environmental metrics were determined in terms of mass of $\mathrm{CO}_{2}$-equivalent greenhouse gases $\left(\mathbf{C O}_{2} \mathbf{e}, \mathrm{kg}\right)$ per functional unit and mass of water per functional unit. The functional unit was defined as $750 \mathrm{~mL}$ of $45 \%$ ethanol, a common commercial unit within the distilled spirits industry (Alcohol and Tobacco Tax and
Trade Bureau, 2012) and will be referred to hereafter as a bottle of spirit. Data were collected at the stages in which inputs and outputs differ in the production process. Each step of the process was considered for all major energy inputs, waste outputs, and $\mathrm{CO}_{2}$ produced during fermentation.

\section{Goal and Scope}

The goal of this study was to compare $\mathrm{CO}_{2} \mathrm{e}$ emissions and water use for the production of $45 \%$ alcohol by volume (ABV) spirits. This study evaluated energy and water input required to produce a bottle of spirit using materials already present on site. Sustainable energy and water use are integral to ensure responsible food production practices to meet the demands of a growing global population (Flammini et al., 2014). The choice to evaluate energy and water inputs enabled us to quantify environmental impacts, and these inputs are common industry measurements used to determine environmental impacts of food and beverage production (Kim et al., 2013; Tsiropoulos et al., 2014; Eriksson et al., 2016). The scope of this study was confined to distillery operations. Thus, only differences in production methods were considered. Other materials and processes used for the production of craft spirits (e.g., agriculture production processes, shipping, packaging, and malting) are common across multiple industries and would not be affected by artisanal spirit production, so they were excluded from the scope of analysis. The process flows for WW and DWS production are outlined in Figure 2. The scope of this study began with the raw fermentation substrate received at the facility and ended before packaging, with the final product be-

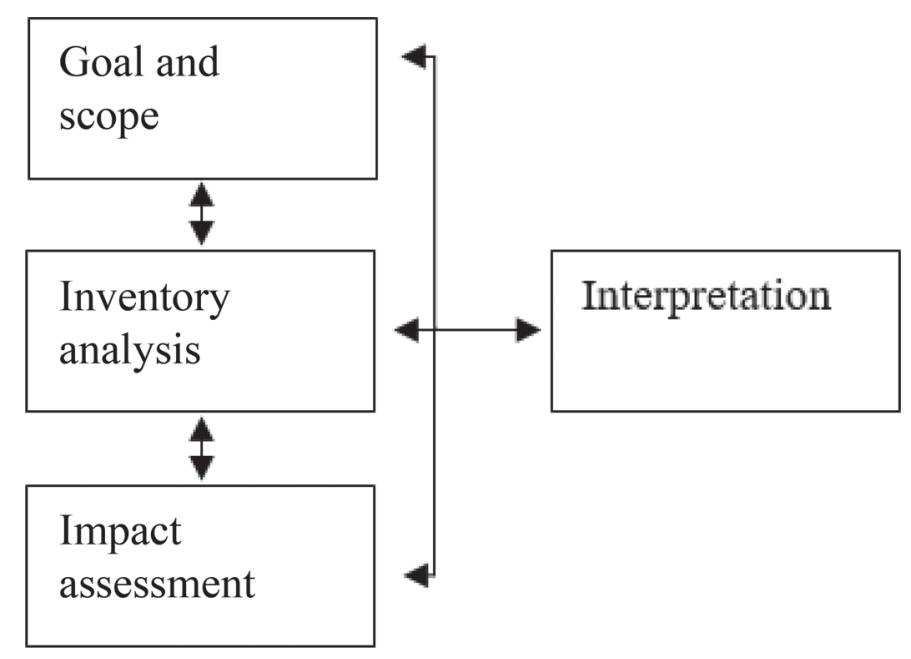

Figure 1. Steps in a life cycle analysis. 
ing diluted to bottling strength, because each product's environmental impacts would be identical beyond this point. The first and greatest difference between the individual products is the removal of all steps before and including "mash" in the DWS process. This is a key point in the overall scope of the study: mashing is a

A.

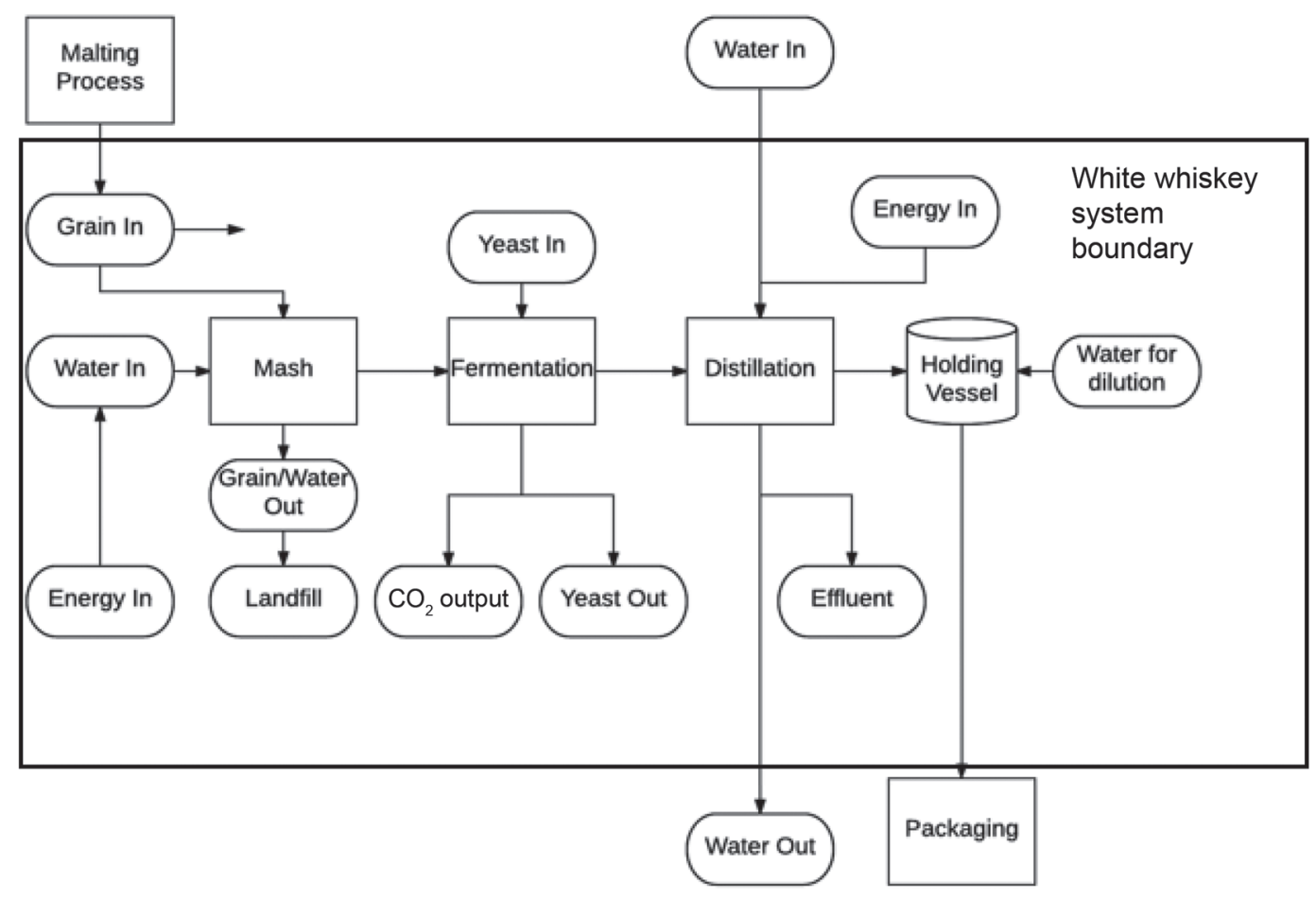

B.

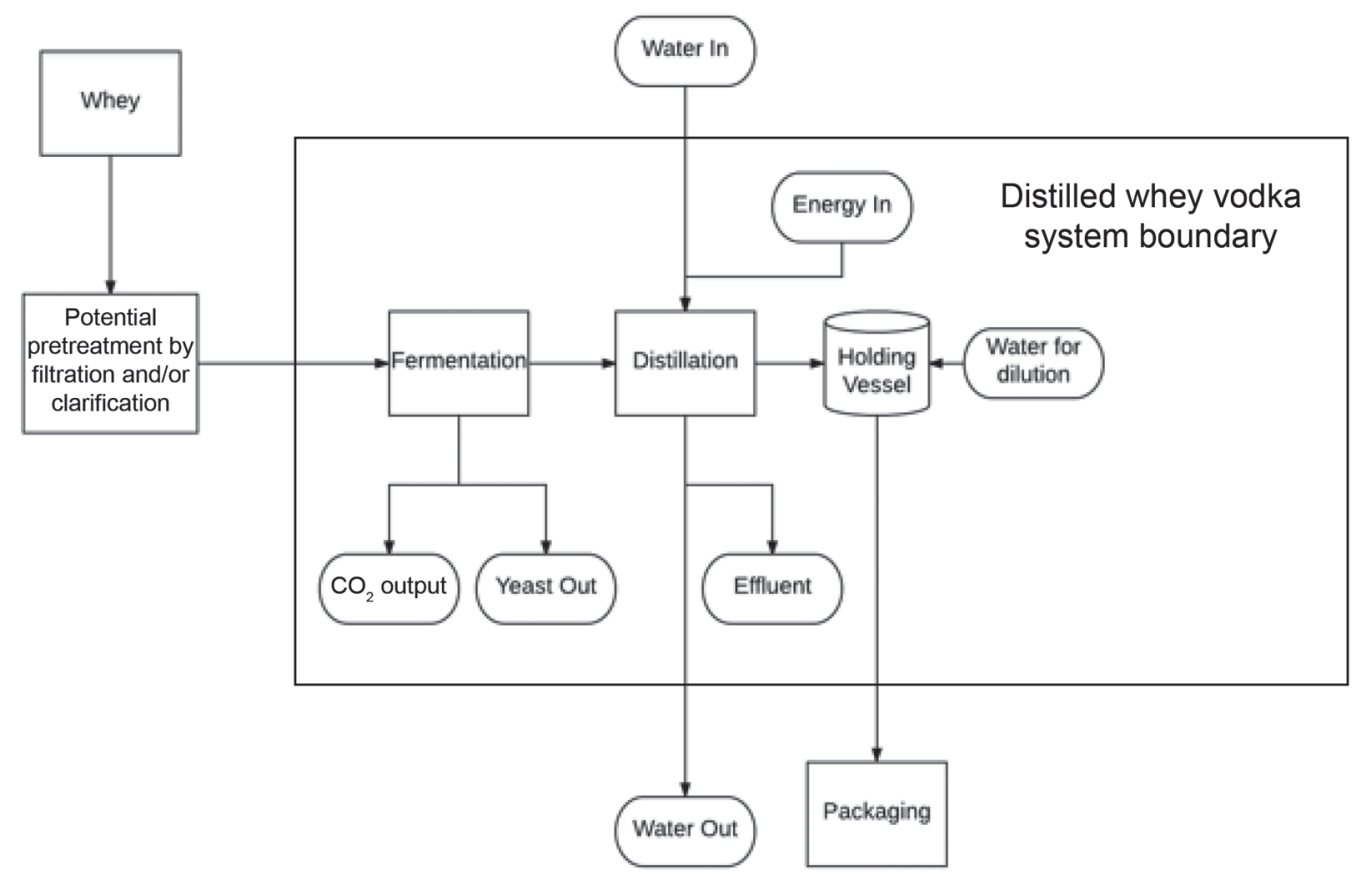

Figure 2. Flow diagrams for (A) white whiskey process, and (B) distilled whey spirit process. 
Table 1. Assumptions used to compare white whiskey (WW) and distilled whey spirit (DWS) production

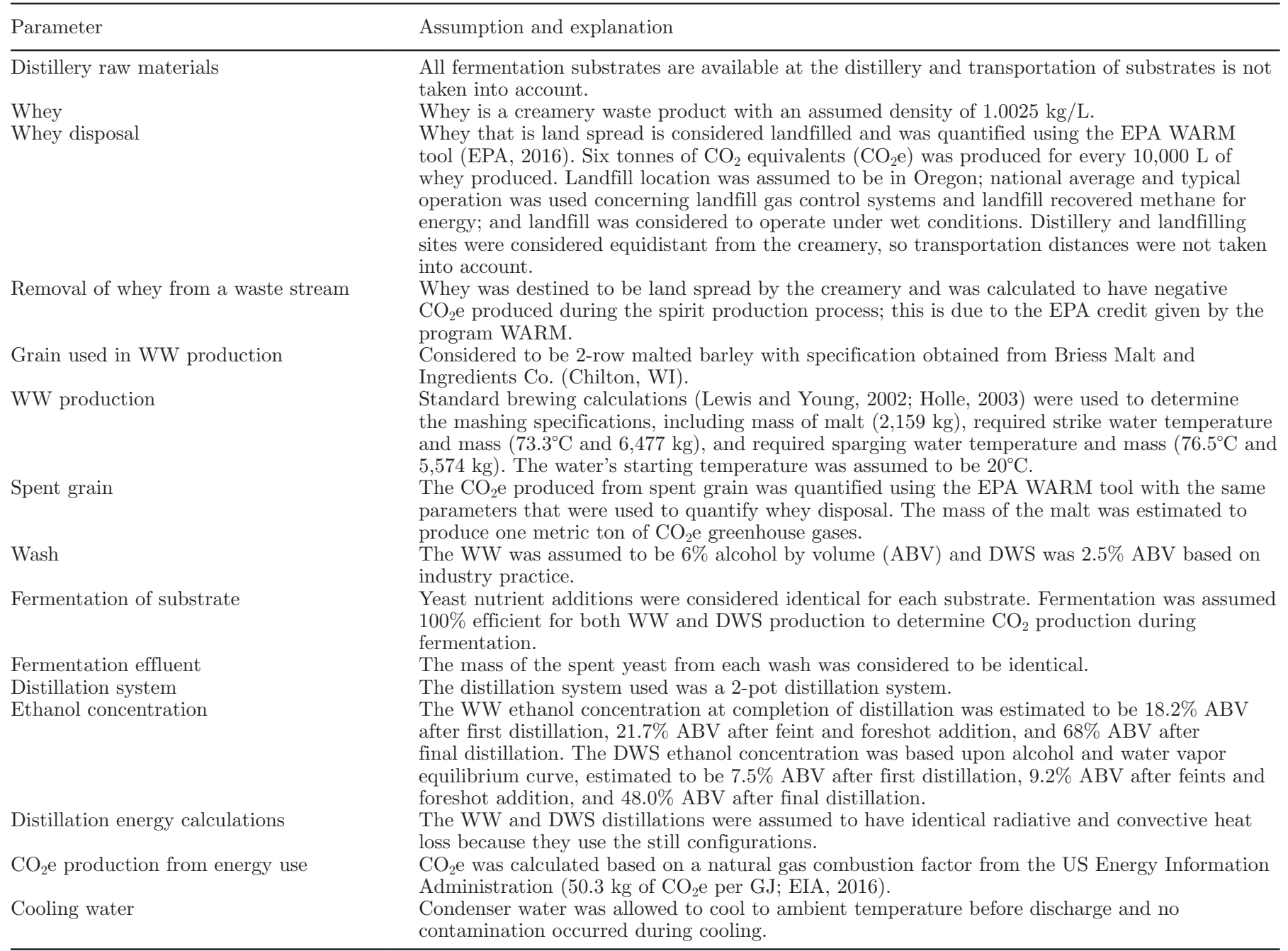

well-known and documented process (Lewis and Young, 2002; Holle, 2003) and requires the inputs of large quantities of water and energy. Traditional whiskey production relies on producing a mash, which extracts and converts grain starch into fermentable sugar.

\section{Life Cycle Inventory}

The life cycle inventory portion of the LCA included quantification of the materials, energy, and water requirements for each of the processes considered within the system boundary. Resource quantification was achieved through calculations related to hypothetical energy and water requirements, mass balance calculations throughout the processes, and logic-based assumptions as described below. Key assumptions are addressed in Table 1.

\section{Fermentation Microorganisms}

The 2 processes utilized different yeasts. Saccharomyces cerevisiae, the standard organism used in whiskey wash fermentation, ferments the extract produced by the mashing process (Lewis and Young, 2002) but cannot ferment lactose. Instead, K. marxianus, a lactose-fermenting yeast, is used to ferment whey. The environmental implications for using $K$. marxianus over S. cerevisiae are not well understood; however, both organisms offer distinct advantages and disadvantages. In terms of an environmental impact evaluation approach, $K$. marxianus is more thermotolerant than $S$. cerevisiae (Guimarães et al., 2010), which could play a role in energy savings, particularly in the summer months when fermentors must be thermo-regulated to maintain optimal fermentation temperatures around $30^{\circ} \mathrm{C}$ for $\mathrm{WW}$ 
and $37^{\circ} \mathrm{C}$ for DWS. These potential energy savings were not accounted for in the LCA. The yeast input and outputs for the fermentation process for each process flow were assumed the same. Although the yeasts are different, each organism is generally recognized as safe (Raimondi et al., 2013; FDA, 2016), which allows both types to be disposed of as animal feed. Therefore, yeast disposal was not considered in the LCA.

\section{Effluent}

Effluent generation was tracked throughout the whole process. The amount of effluent for distilling included the pot ale removed from the wash still and the spent lees removed from the spirit still (Figure 3). The volume of pot ale waste leaving the wash still was calculated to be equal between WW and DWS production and was not included in the LCA. The assumption was made that the distillery was in operation twice a week, giving condenser water time to cool to ambient temperature before entering the municipal water system.

\section{Energy Input}

Energy uses in the distillation process were calculated based on a model distillation system flowchart based on standard industry practices (Figure 3). The actual distillation process was assumed identical for each product. However, inputs into the system were different because of differences in percent $\mathrm{ABV}$ of the fermented substrate $2.5 \% \mathrm{ABV}$ for DWS and $6 \% \mathrm{ABV}$ for WW), which affects energy input. The \%ABV of the WW after each distillation was determined using common industry conventions and a mass-balance flowchart (Piggot, 2009; Hughes and Buxton, 2014; Nicol, 2014). The \%ABV of DWS after each distillation was determined using a vapor-liquid equilibrium graph from Purdue University (Kvaalen et al., 1984) and a mass-balance flowchart (Figure 3).

Energy requirements for the distilling process were tracked based on ethanol and water ratios by mass flows within the system. Established standard reference tables were used throughout the mass-balance process to determine the density of ethanol-water solutions and to convert \% ABV to percentage alcohol by weight (International Organisation of Legal Metrology, 1973).

The required energy to bring each component (ethanol and water) up to $95^{\circ} \mathrm{C}$ in the wash still and $90^{\circ} \mathrm{C}$ in the spirit still from $20^{\circ} \mathrm{C}$ were calculated separately for each process flow. The energy required to evaporate each component was also taken into account. These calculations were made using standard heat-transfer and vaporization equations (Singh and Heldman, 2014), as shown below.

Equation [1] gives the energy for heat transfer:

$$
Q=M \times C_{p} \times \Delta T,
$$

where $Q=$ energy $(\mathrm{kJ}), M=\operatorname{mass}(\mathrm{kg}), C_{p}=$ specific heat $\left(\mathrm{kJ}^{\mathrm{k}} \cdot \mathrm{kg}^{-1}{ }^{\circ} \mathrm{C}^{-1}\right)$, and $\Delta T=$ change in temperature $\left({ }^{\circ} \mathrm{C}\right)$.

Equation [2] gives the energy of vaporization:

$$
Q=M \times L,
$$

where $Q$ and $M$ are as defined above and $L=$ latent heat of vaporization $\left(\mathrm{kJ} \cdot \mathrm{kg}^{-1}\right)$

Heat loss throughout the distillation process was assumed identical for each production process and therefore not included. The calculation method and process flowcharts are adapted from known whiskey still configurations and use standard thermodynamic relationships as described above (Hughes and Buxton, 2014; Nicol, 2014; Singh and Heldman, 2014).

\section{Water Input}

Water going into the distillation process was split into 3 categories: (1) water in-to condense the distillate; (2) waste water - water leaving the system from the spirit still; and (3) water for dilution-water used to bring the final distillate to the proper functional unit ethanol concentration.

Water usage in the 2 processes, except for dilution volume, was assumed identical and not a contributing factor to overall environmental impact of the distillation process. We assumed that water was recycled and not contaminated in any meaningful way. Wastewater was assumed to consist of water and spent lees from the spirit and was assumed to be disposed through the municipal water system. Water for dilution of the spirit to $45 \% \mathrm{ABV}$ varied due to differences in initial \% ABV of the 2 distillates: WW required a dilution from $68 \%$ $\mathrm{ABV}$ and DWS required a dilution from $48 \% \mathrm{ABV}$ to a commercial strength of $45 \%$ ABV.

\section{Mash Step}

To assess the environmental impact of the removal of the mash step (Figure 4), energy, total mass of grain required, and water usage were quantified. The amount of grain and water required were calculated by developing a recipe that would produce a $6 \% \mathrm{ABV}$ wash using brewing calculations (Lewis and Young, 2002; Holle, 
A.
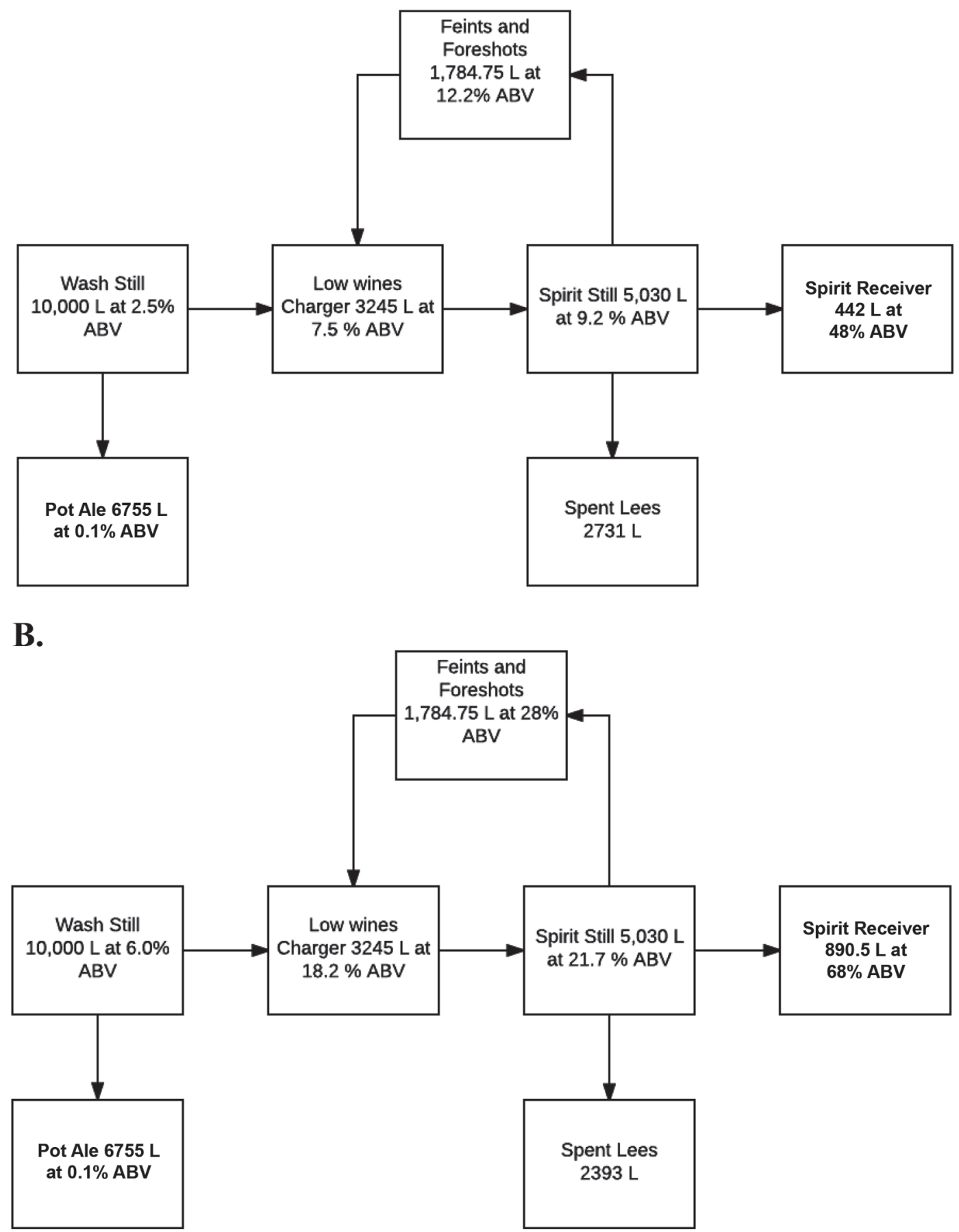

Figure 3. Pot distillation process for (A) distilled whey spirit (DWS), and (B) white whiskey (WW). ABV = alcohol by volume.

2003), such as that in Equation [3] for calculating the grain mass to be added:

$$
\frac{\text { wort volume } \times \rho \times S G \times{ }^{\circ} P}{\% \text { extract } \times(1-\% \text { moisture }) \times \omega}=\text { Mass }_{\text {grain }},
$$

where $\rho=$ density of water $(\mathrm{kg} / \mathrm{L}), S G=$ desired beer specific gravity with reference of density of water, ${ }^{\circ} \mathrm{P}$ $=$ desired Plato (grams of solute/grams of solution), $\%$ extract was on a dry basis, coarse grind (value from malt specification sheet), $\%$ moisture $=$ percentage of 


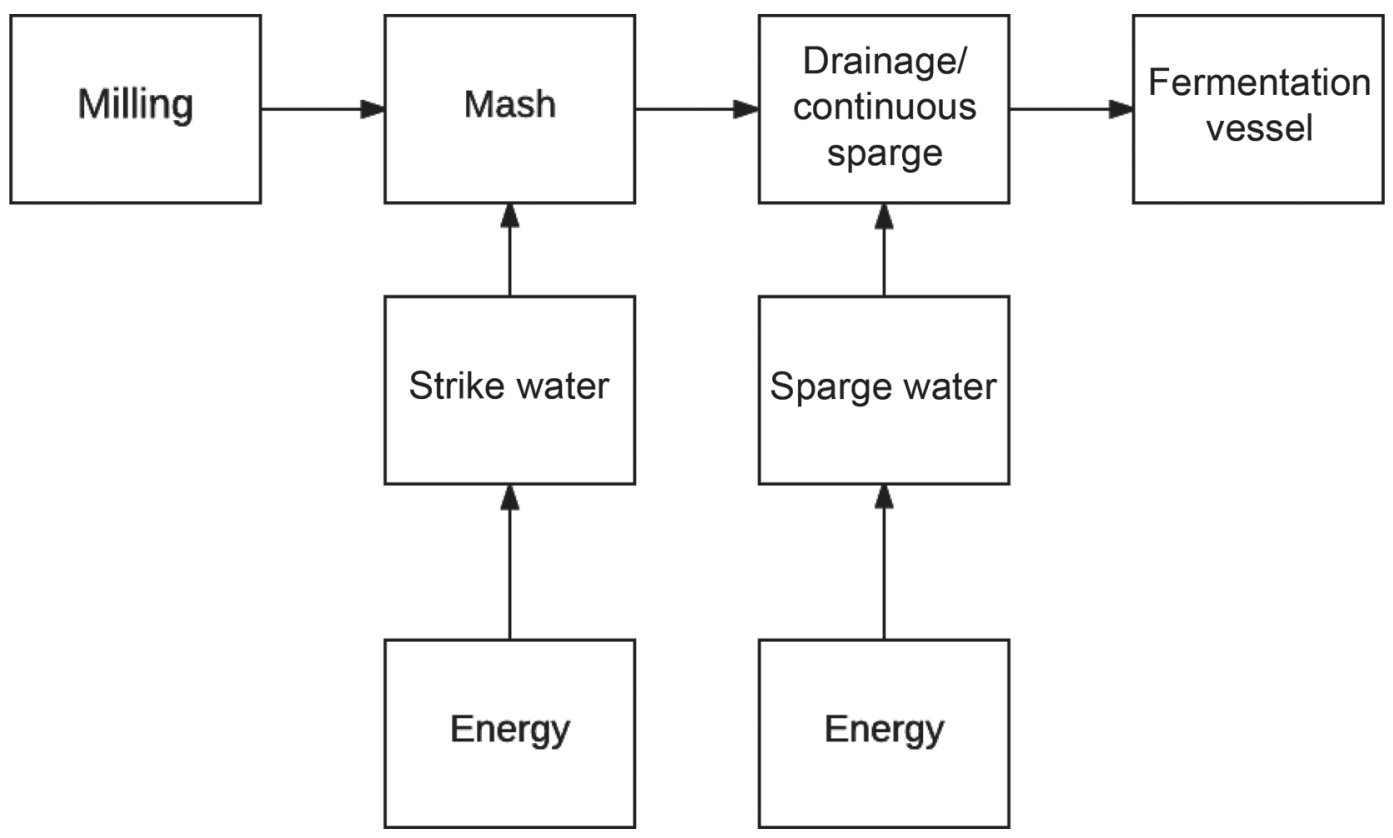

Figure 4. Mashing process for white whiskey production.

moisture from malt specification sheet, and $\omega=$ brewhouse efficiency (varies from site to site).

The malt specifications were obtained from a specialty malting supply company (Briess Malt and Ingredients Co., 2016) and are noted in Table 2. The total volume of water required by the mashing process was determined by taking into account water retained by the grain $(0.96 \mathrm{~L} / \mathrm{kg}$ of malt), assuming there were no evaporative losses and considering the volume of wort required for the recipe. The mashing process included 2 steps, the addition of strike water and addition of sparge water, as noted in Figure 4. The temperature and volume of the strike water were determined using common brewing conventions, including water being added at a 3:1 (wt/wt) water:grain ratio, the specific heat of grain being $40 \%$ of that for water, and the desired mash temperature being $67^{\circ} \mathrm{C}$ (Lewis and Young, 2002; Holle, 2003). This phase converts the starches in the mash to fermentable sugars. The required temperature for the strike water was determined to be $73.3^{\circ} \mathrm{C}$ based upon

Table 2. Mash recipe and grain specifications

\begin{tabular}{ll}
\hline Parameter & Specification \\
\hline Specific gravity (SG) & 1.057 \\
Extract ( ${ }^{\circ}$ Plato) & $14 \mathrm{~g} / 100 \mathrm{~g}$ of solution \\
Water density $(\rho)$ & $1 \mathrm{~kg} / \mathrm{L}$ \\
$\%$ Extract (dry basis) & 0.795 \\
$\%$ Moisture & 0.042 \\
Brewhouse efficiency $(\omega)$ & 0.90 \\
\hline
\end{tabular}

the recipe detailed in Table 2. The second phase of the mashing process, a drainage/continuous sparge, is used to rinse the grains of any fermentable sugars that remain after the strike water is drained. According to common brewing conventions, sparge water is heated to $76.5^{\circ} \mathrm{C}$ and the remainder of the total determined volume of water is used during drainage/continuous sparge step (Lewis and Young, 2002; Holle, 2003). After the required water temperatures were determined for each mashing step, the amount of energy required to raise the water temperature to the desired level from $20^{\circ} \mathrm{C}$ was calculated using the thermodynamic calculations detailed in equation [1] (Singh and Heldman, 2014).

\section{Substrate Pretreatment}

To ensure healthy, successful fermentations, each substrate would be treated with yeast nutrient and diammonium phosphate; these additions were considered identical. Industrial cheese producers have the capability to process whey to recover fat and protein via centrifugation and membrane filtration (Tetra Pak, 2015a). Whey permeate processed in this manner would still provide a viable fermentation substrate. The processing of whey in this manner falls outside the predetermined system boundary. This study assumed that whey had not been processed in this manner because artisanal creameries generally lack the required infrastructure and equipment need for such processing. If whey permeate were used as a fermentation substrate, it could reduce water used during the cleaning process. 


\section{Emissions of $\mathrm{CO}_{2}$ from Fermentation}

The $\mathrm{CO}_{2}$ generated during fermentation was taken into account as it represented a direct source of $\mathrm{CO}_{2}$ produced in the process. Theoretically, for every $1 \mathrm{~kg}$ of fermentable substrate, $0.538 \mathrm{~kg}$ of ethanol and $0.462 \mathrm{~kg}$ of $\mathrm{CO}_{2}$ are generated (Koushki et al., 2012). Using this assumption, an estimate of the mass of $\mathrm{CO}_{2}$ emitted during fermentation could be determined based upon the mass of the ethanol produced by the yeast. The fermentations were assumed ideal and did not account for the conversion of substrate for cell mass growth, with DWS wash starting at $2.5 \% \mathrm{ABV}$ and WW wash starting at $6 \% \mathrm{ABV}$. Each fermentation substrate has a similar protein content (Jancar et al., 1983; Tetra Pak, 2015a) so any treatments to prevent foaming during the distillation process or post-distillation cleaning process were considered identical. The mass of ethanol was calculated assuming an ethanol density of $789 \mathrm{~kg} / \mathrm{m}^{3}$ (International Organisation of Legal Metrology, 1973). Once the mass of ethanol was calculated, the mass of $\mathrm{CO}_{2}$ produced during fermentation could be found using the example calculation shown below:

$$
\begin{aligned}
& 10,000 \mathrm{~L} \times 6 \% \mathrm{ABV} \\
& =600 \mathrm{~L} \text { of ethanol } \times \frac{1 \mathrm{~m}^{3}}{1,000 \mathrm{~L}} \times 789 \mathrm{~kg} / \mathrm{m}^{3} \\
& =473.4 \mathrm{~kg} \text { of ethanol; } \\
\mathrm{CO}_{2} & =473.4 \mathrm{~kg} \text { of ethanol } \times \frac{0.462 \mathrm{~kg} \text { of } \mathrm{CO}_{2}}{0.538 \mathrm{~kg} \text { of ethanol }} \\
= & 406.5 \mathrm{~kg} \text { of } \mathrm{CO}_{2} .
\end{aligned}
$$

In addition to direct $\mathrm{CO}_{2}$ emissions, indirect $\mathrm{CO}_{2} \mathrm{e}$ emissions were estimated by examining the energy use of the 2 production systems. The difference in required heating energy from natural gas combustion for the 2 systems was calculated. Next, $\mathrm{CO}_{2} \mathrm{e}$ emissions were determined using an emissions factor of $50.3 \mathrm{~kg}$ of $\mathrm{CO}_{2} \mathrm{e}$ per GJ for natural gas (EIA, 2016). The Waste Reduction Model software tool (WARM v.14; https://www .epa.gov/warm/versions-waste-reduction-model-warm \#WARM Tool V14) developed by the US Environmental Protection Agency (EPA; EPA, 2016) was used to estimate both the reduction of $\mathrm{CO}_{2} \mathrm{e}$ emissions from removing whey from a waste stream and the impact of grain disposal in terms of $\mathrm{CO}_{2} \mathrm{e}$ emissions.

\section{Life Cycle Impact Assessment}

As mentioned above, life cycle impact assessment was completed to compare the 2 systems using 2 metrics: greenhouse gas production $\left(\mathrm{kg}\right.$ of $\left.\mathrm{CO}_{2} \mathrm{e}\right)$ and water us- age ( $\mathrm{kg}$ of water). The WARM software tool (EPA, 2016) was used to quantify the impact of spent grain waste from the mashing process and removal of whey from the dairy waste stream on the environment in terms of $\mathrm{CO}_{2}$ e production. The WARM tool allowed us to categorize the waste materials and provided a calculator to determine the mass of $\mathrm{CO}_{2} \mathrm{e}$ emitted per tonne of material based on the categorization of waste. Spent grain was categorized as grain waste and whey was categorized as dairy waste. The mass of a 10,000-L batch of whey was calculated using industry data on milk density (Tetra Pak, 2015b).

The whey was given a credit for $\mathrm{CO}_{2} \mathrm{e}$ emissions (negative value for $\mathrm{CO}_{2} \mathrm{e}$ emissions) because it was removed from a waste system. In the WARM tool, we considered whey to be landfilled due to the practice of field spreading used by many artisan cheese companies. Because the distillery and landfill were assumed equidistant from the creamery, the travel distance from the creamery to the landfill was set at zero in the calculator to avoid factoring in vehicular emissions (i.e., no net difference in emissions). Grain waste was considered landfilled and converted to mass of $\mathrm{CO}_{2} \mathrm{e}$ emissions using the WARM tool. The calculated energy values were converted to mass of $\mathrm{CO}_{2} \mathrm{e}$ emissions based on the energy produced through burning of natural gas.

\section{Sensitivity Analysis}

The $\mathrm{CO}_{2}$ e emissions were changed by $\pm 25 \%$ for each production step listed in Table 4, and impact to total $\mathrm{CO}_{2} \mathrm{e}$ emissions produced by each production process was tracked.

\section{RESULTS AND DISCUSSION}

The differences in environmental impacts between WW production and DWS production are influenced by 2 key factors: removal of whey from the waste stream and disposal method used for the spent grain. The removal of whey from a landfill-destined waste stream reduces the $\mathrm{CO}_{2} \mathrm{e}$ greenhouse gases by $6 \mathrm{t} / 10,000 \mathrm{~L}$ of whey according to WARM (EPA, 2016). The landfilling of spent grain produces approximately $1 \mathrm{t}$ of $\mathrm{CO}_{2} \mathrm{e}$ emissions. On the other hand, anaerobic digestion and composting produce no additional emissions. White whiskey required an additional 2 GJ of energy per 10,000 L batch due to the additional mashing step (Table 3). Energy use for each process was converted to mass of $\mathrm{CO}_{2} \mathrm{e}$ using reported emissions factors for natural gas (EIA, 2016). The fermentation of WW produced more direct $\mathrm{CO}_{2}$ than DWS (406 vs. $169 \mathrm{~kg}$ of $\mathrm{CO}_{2} \mathrm{e}$ per 10,000 L of wash) due to the additional substrate available to the microbes from the mashing process. 
Table 3. Calculated process differences of white whiskey (WW) and distilled whey spirit (DWS)

\begin{tabular}{|c|c|c|c|c|}
\hline \multirow[b]{2}{*}{ Production step } & \multicolumn{2}{|c|}{ Energy input (GJ) } & \multicolumn{2}{|c|}{ Output (kg) } \\
\hline & WW & DWS & WW & DWS \\
\hline Mashing (spent grains) & 2.8 & 0.0 & 4,230 & 0 \\
\hline Fermentation $\left(\mathrm{CO}_{2}\right)$ & - & - & 407 & 169 \\
\hline Wash still distillation & 9.5 & 10.1 & - & - \\
\hline Spirit still distillation (spent lees) & 5.7 & 5.9 & 2,393 & 2,731 \\
\hline Total & 18.0 & 16.0 & 7,030 & 2,900 \\
\hline
\end{tabular}

However, the different masses of $\mathrm{CO}_{2} \mathrm{e}$ emissions during fermentation and energy became negligible when examined from a functional unit perspective

Ten thousand liters of wash produced more WW than DWS (1,792 vs. 628 bottles per batch). The total $\mathrm{CO}_{2} \mathrm{e}$ emission per 10,000 $\mathrm{L}$ of wash processed is summarized in Table 4 . The disparity between batch sizes requires examination at the functional unit level to understand the environmental impacts related to each process. To conduct an examination at a functional unit level, the total mass of $\mathrm{CO}_{2} \mathrm{e}$ greenhouse gases produced per batch was divided the total number of bottles produced by each batch. A DWS batch produced a volume of spirit approximately one-third of that of the WW batch. To compensate for this batch size disparity, only $35 \%$ of greenhouse gases and water used per 10,000 L batch of WW were accounted to determine the environmental impact per bottle. Removal of whey from the landfill waste stream to produce DWS reduced net $\mathrm{CO}_{2} \mathrm{e}$ emissions by $8 \mathrm{~kg}$ per bottle. In contrast, production of WW increased total net $\mathrm{CO}_{2}$ e emissions by approximately $0.45 \mathrm{~kg}$ per bottle. Thus, producing DWS instead of WW would reduce net $\mathrm{CO}_{2} \mathrm{e}$ emissions by approximately $8.45 \mathrm{~kg}$ per bottle. Water inputs required for DWS production were $0.44 \mathrm{~kg}$ less per bottle than for WW production. This reduction was largely due to the elimination of the mashing step and differences in the required dilution to commercial spirit strength. This leads us to the apparent economic and environmental advantages of DWS production: a large resource sink is eliminated because no substrate preparation is necessary and whey is removed from a waste stream that otherwise produces $\mathrm{CO}_{2} \mathrm{e}$ greenhouse gases.
The following assumptions are critical to the validity of these results: whey is removed from a landfill-type waste stream and DWS is produced instead of WW. The removal of whey from a waste stream is critical because it eliminates the production of $\mathrm{CO}_{2} \mathrm{e}$ greenhouse gases associated with landfilling. The production assumptions for DWS are critical because this analysis compared the environmental impacts of DWS and WW based only on the differences in their production processes.

If these assumptions were true, DWS production would emit $8.4 \mathrm{~kg}$ less $\mathrm{CO}_{2}$ e greenhouse gases per bottle than WW production. Also, DWS production would use $0.44 \mathrm{~kg}$ less water than WW production. If the assumptions were not true; for example, if whey were generated solely for production of a potable spirit or if DWS would not replace another spirit in the marketplace, then the results of this study would not be valid.

The sensitivity analysis indicated that the parameter with the greatest impact on net $\mathrm{CO}_{2} \mathrm{e}$ emissions was removal of whey from the landfill waste stream. After a $25 \%$ reduction in $\mathrm{CO}_{2} \mathrm{e}$ emissions credit was applied to the removal from waste production step, net $\mathrm{CO}_{2} \mathrm{e}$ emissions per bottle were recalculated, and the net reduction decreased from 8.4 to $6 \mathrm{~kg}$ of $\mathrm{CO}_{2} \mathrm{e}$ per bottle. When this procedure was applied to the whey distillation process by increasing the amount of $\mathrm{CO}_{2} \mathrm{e}$ emissions produced in the process by $25 \%$, the net reduction of $\mathrm{CO}_{2} \mathrm{e}$ only decreased from 8.4 to $8 \mathrm{~kg}$ per bottle. In the case where spent grain is sent to the landfill, this would be the single most impactful parameter associated with WW production. It should be noted that if the mashing, fermentation, and distilla-

Table 4. Carbon dioxide-equivalent $\left(\mathrm{CO}_{2} \mathrm{e}\right)$ emissions produced during production processes

\begin{tabular}{lcc}
\hline Production step & $\begin{array}{c}\text { White whiskey } \\
\left(\mathrm{kg} \text { of } \mathrm{CO}_{2} \mathrm{e}\right)\end{array}$ & $\begin{array}{c}\text { Distilled whey spirit } \\
\left(\mathrm{kg} \text { of } \mathrm{CO}_{2} \mathrm{e}\right)\end{array}$ \\
\hline Removal from waste stream & - & $-6,000$ \\
Mashing & 138 & - \\
Fermentation & 406 & 169 \\
Distillation & 768 & 803 \\
Landfilled spent grain & 1,000 & $-5,028$ \\
Total & 2,312 & \\
\hline
\end{tabular}


tion were considered a single process, then this process would have a greater effect on net $\mathrm{CO}_{2} \mathrm{e}$ emissions than the landfilling of spent grain. This provides evidence that removal of whey from a landfill waste stream is the variable having the greatest impact in this process.

As seen in the LCA of WW production, one of the primary contributors to total $\mathrm{CO}_{2} \mathrm{e}$ emissions was the disposal of spent grain from the mashing process. Although removing mashing significantly reduced the overall impact of DWS, attention is needed to other sources of bio-waste from every part of the distillation process. By using most of the available nutrient content of whey for fermentation, the remainder of the biological and chemical oxygen demand that has not been reduced is largely sequestered as biomass in the form of yeast. Significant work has been done on the treatment of distillery and brewery effluent (Butt, 1993; Fillaudeau et al., 2006; Devesa-Rey et al., 2011), focusing on yeast treatment for animal feed and fertilizer. Despite this earlier research, understanding the overall environmental impact of distillery effluent remains incomplete. Research into the true value of post-fermentation products is also necessary to fully assess the environmental and economic impacts of these processes.

Review of the production of WW and DWS has yielded valuable insights into the environmental implications for the artisanal cheese and craft distillation industries. The process-based LCA undertaken herein estimates that distillation of fermented whey can reduce systemic $\mathrm{CO}_{2} \mathrm{e}$ emissions by $8.4 \mathrm{~kg}$ per $750 \mathrm{~mL}$ of DWS produced, while requiring $0.44 \mathrm{~kg}$ less water added into the production process compared with the production of WW, a similar clear, unaged spirit produced using malted barley. This analysis suggests that conversion to DWS is a more environmentally responsible approach than WW spirit production and whey disposal by landfilling. It should be noted that these conclusions apply to distilleries using a pot distillation system. As production of ethanol is scaled up, equipment used in the distillation process changes. Continuous distillation is often used for large-scale ethanol manufacture and has been applied to whey distillation on an industrial level in Ireland and New Zealand (Ling, 2008). The Carbery process has been used by a New Zealand company to produce over 18 million liters of ethanol annually. This process involves the use of continuous distillation equipment not examined in this study (Ling, 2008). Additional research would be required to examine the environmental impact of DWS produced in this manner.

Further research into the production of DWS as an environmentally friendly, value-added product is war- ranted by craft distilleries and artisanal creameries. Besides lowering the environmental impact of whey disposal, DWS provides significant value-added potential for distilleries as the current craft spirit market expands. In particular, the production of DWS at the craft level may yield a beneficial partnership between a small, artisanal creamery desiring a sustainable means of whey disposal and a craft distillery seeking an economic advantage.

\section{ACKNOWLEDGMENTS}

This research was supported by the Oregon State University's Arbuthnot Dairy Center and STILLab.

\section{REFERENCES}

Alcohol and Tobacco Tax and Trade Bureau. 2012. The Beverage Alcohol Manual (BAM) A Practical Guide: Basic Mandatory Labeling Information for Distilled Spirits. Department of the Treasury, Washington, DC.

Black Cow. 2017. Black Cow vodka. Accessed Nov. 16, 2017. http:// www.blackcow.co.uk/.

Briess Malt \& Ingredients Co. 2016. Product information and typical analysis of brewers malt. Accessed Dec. 5, 2016. http://www .brewingwithbriess.com/Products/Base.htm.

Butt, K. R. 1993. Utilisation of solid paper-mill sludge and spent brewery yeast as a feed for soil-dwelling earthworms. Bioresour. Technol. 44:105-107. https://doi.org/10.1016/0960-8524(93)90182-B.

Chatzipaschali, A. A., and A. G. Stamatis. 2012. Biotechnological utilization with a focus on anaerobic treatment of cheese whey: Current status and prospects. Energies 5:3492-3525. https://doi.org/ 10.3390/en5093492.

Devesa-Rey, R., X. Vecino, J. L. Varela-Alende, M. T. Barral, J. M. Cruz, and A. B. Moldes. 2011. Valorization of winery waste vs. the costs of not recycling. Waste Manag. 31:2327-2335. https://doi .org/10.1016/j.wasman.2011.06.001.

Diniz, R. H. S., M. Q. R. B. Rodrigues, L. G. Fietto, F. M. L. Passos, and W. B. Silveira. 2014. Optimizing and validating the production of ethanol from cheese whey permeate by Kluyveromyces marxianus UFV-3. Biocatal. Agric. Biotechnol. 3:111-117. https:// doi.org/10.1016/j.bcab.2013.09.002.

Dragone, G., S. I. Mussatto, J. B. Almeida e Silva, and J. A. Teixeira 2011. Optimal fermentation conditions for maximizing the ethanol production by Kluyveromyces fragilis from cheese whey powder. Biomass Bioenergy 35:1977-1982. https://doi.org/10.1016/j .biombioe.2011.01.045.

Dragone, G., S. I. Mussatto, J. M. Oliveira, and J. A. Teixeira. 2009. Characterisation of volatile compounds in an alcoholic beverage produced by whey fermentation. Food Chem. 112:929-935. https://doi.org/10.1016/j.foodchem.2008.07.005.

EIA (US Energy Information Association). 2016. Carbon dioxide emissions coefficients. Accessed December 1, 2016. https://www.eia .gov/environment/emissions/co2_vol_mass.cfm.

Eriksson, O., D. Jonsson, and K. Hillman. 2016. Life cycle assessment of Swedish single malt whisky. J. Clean. Prod. 112:229-237. https://doi.org/10.1016/j.jclepro.2015.07.050.

EPA (US Environmental Protection Agency). 2016. Waste Reduction Model. US EPA, Washington, DC. Accessed Jan. 10, 2018. https://www.epa.gov/warm/versions-waste-reduction-model -warm\#WARM Tool V14.

FDA. 2016. Microorganisms and microbial-derived ingredients used in food (partial list). Accessed Dec. 5, 2016. http:// www.fda.gov/Food/IngredientsPackagingLabeling/GRAS/ MicroorganismsMicrobialDerivedIngredients/default.htm. 
Fillaudeau, L., P. Blanpain-Avet, and G. Daufin. 2006. Water, wastewater and waste management in brewing industries. J. Clean Prod. 14:463-471. https://doi.org/10.1016/j.jclepro.2005.01.002.

Flammini, A., M. Puri, L. Pluschke, and O. Dubois. 2014. Walking the nexus talk: Assessing the water-energy-food nexus in the context of the sustainable energy for all initiative. Climate, Energy and Tenure Division (NRC), Food and Agriculture Organization of the United Nations, Rome, Italy.

Guimarães, P. M. R., J. A. Teixeira, and L. Domingues. 2010. Fermentation of lactose to bio-ethanol by yeasts as part of integrated solutions for the valorisation of cheese whey. Biotechnol. Adv. 28:375-384. https://doi.org/10.1016/j.biotechadv.2010.02.002.

Hadiyanto, D. Ariyanti, A. P. Aini, and D. S. Pinundi. 2014. Optimization of ethanol production from whey through fed-batch fermentation using Kluyveromyces marxianus. Energy Procedia 47:108-112. https://doi.org/10.1016/j.egypro.2014.01.203.

Holle, S. 2003. A Handbook of Basic Brewing Calculations. 4th ed. Master Brewers Association of Americas, St. Paul, MN.

Hughes, P., and I. Buxton. 2014. Crop-to-cask production of new make spirit. Pages $90-133$ in The Science and Commerce of Whisky, The Royal Society of Chemistry, Cambridge, UK.

International Organisation of Legal Metrology. 1973. International alcoholometric tables. https://www.oiml.org/en/files/pdf_r/r022 -e75.pdf.

ISO. 2006. ISO 14040: Environmental management: Life cycle assessment-Principles and framework. International Organization for Standardization (ISO), Geneva, Switzerland.

Jancar, J. C., M. D. Constant, and W. C. Herwig. 1983. Protein content of beer and wort by pyrochemiluminescence. J. Am. Soc. Brew. Chem. 41:158-160. https://doi.org/10.1094/ASBCJ-41-0158.

Kim, D., G. Thoma, D. Nutter, F. Milani, R. Ulrich, and G. Norris. 2013. Life cycle assessment of cheese and whey production in the USA. Int. J. Life Cycle Assess. 18:1019-1035. https://doi.org/10 .1007/s11367-013-0553-9.

Koushki, M., M. Jafari, and M. Azizi. 2012. Comparison of ethanol production from cheese whey permeate by two yeast strains. J. Food Sci. Technol. 49:614-619. https://doi.org/10.1007/s13197 -011-0309-0.

Kvaalen, E., P. Wankat, and B. McKenzie. 1984. Alcohol Distillation: Basic Principles, Equipment, Performance Relationships and Safety. Purdue University, West Lafayette, IN.

Lewis, M., and T. Young. 2002. Brewing. 2nd ed. Kluwer Academic/ Plenum Publisher, New York, NY.
Ling, C. 2008. Whey to Ethanol: A Biofuel Role for Dairy Cooperatives? USDA Rural Development, Washington, DC.

Lozier, C. 2017. The craft spirits data project. Artisan Spirit 17:69-73. http://www.parkstreet.com/wp-content/uploads/ArtisanSpirit Issue017_CSDP.pdf.

Nicol, D. 2014. Batch Distillation. 2nd ed. Elsevier, Oxford, UK.

Piggot, R. 2009. Beverage Alcohol Distillation. 5th ed. Nottingham University Press, Nottingham, UK.

Prazeres, A. R., F. Carvalho, and J. Rivas. 2012. Cheese whey management: A review. J. Environ. Manage. 110:48-68. https://doi .org/10.1016/j.jenvman.2012.05.018.

Raimondi, S., E. Zanni, A. Amaretti, C. Palleschi, D. Uccelletti, and M. Rossi. 2013. Thermal adaptability of Kluyveromyces marxianus in recombinant protein production. Microb. Cell Fact. 12:34 https://doi.org/10.1186/1475-2859-12-34.

Rogosa, M., H. Browne, and E. Whittier. 1947. Ethyl alcohol from whey. J. Dairy Sci. 30:263-269.

Scientific Applications International Corporation. 2006. Life Cycle Assessment: Principles and Practice. US Environmental Protection Agency, Cincinnati, $\mathrm{OH}$

Singh, P., and D. Heldman. 2014. Introduction to Food Engineering. 5th ed. Elsevier, San Diego, CA.

Siso, M. I. G. 1996. The biotechnological utilization of cheese whey: A review. Bioresour. Technol. 57:1-11. https://doi.org/10.1016/0960 -8524(96)00036-3.

Tetra Pak. 2015a. Whey processing. Dairy Processing Handbook. Accessed Oct. 11, 2016. http://www.dairyprocessinghandbook.com/ chapter/whey-processing.

Tetra Pak. 2015b. The chemistry of milk. Dairy Processing Handbook. Accessed Oct. 11, 2016. http://www.dairyprocessinghandbook .com/chapter/whey-processing.

Tsiropoulos, I., A. P. C. Faaij, J. E. A. Seabra, L. Lundquist, U. Schenker, J.-F. Briois, and M. K. Patel. 2014. Life cycle assessment of sugarcane ethanol production in India in comparison to Brazil. Int. J. Life Cycle Assess. 19:1049-1067. https://doi.org/10.1007/ s11367-014-0714-5.

Vermont White. 2016. Vermont White vodka. Accessed Nov. 2, 2016. http://www.vermontspirits.com/products-vermont-white.php.

Whittier, E. 1944. Lactose and its utilization: A review. J. Dairy Sci. $27: 505-537$ 